\title{
JM
}

Volume 7 No. 2 (Oktober 2019)

(C) The Author(s)

\section{ANALISIS FAKTOR YANG BERHUBUNGAN DENGAN KEHAMILAN REMAJA DI KOTA BATAM TAHUN 2019}

\author{
THE CORRELATION OF ANALYSIS FACTORS TEENAGER'S \\ PREGNANCY AT BATAM CITY 2019
}

\author{
DESI PRAMITA SARI, TRISNA YUNI HANDAYANI, KEFIN YOLANDA \\ PROGRAM STUDI D3 KEBIDANAN STIKES MITRA BUNDA PERSADA BATAM \\ Email: chypramitha24@gmail.com
}

\begin{abstract}
ABSTRAK
Masa remaja merupakan masa peralihan yang bias menyebabkan terjadi berbagai masalah kesehatan yaitu perkawinan dan kehamilan usia dini, IMS (Infeksi Menular Seksual), ISR (Infeksi Saluran Reproduksi), HIV/AIDS. Angka kejadian kehamilan remaja diseluruh dunia tidak dapat diperkirakan secara pasti. Sekitar 16 juta kelahiran terjadi pada ibu yang berusia 1519 tahun atau 11\% dari seluruh kelahiran di dunia yang mayoritas (95\%) terjadi di negara sedang berkembang. Tujuan penelitian mengetahui dan menjelaskan faktor yang berhubungan dengan kehamiln remaja di Kota Batam tahun 2019. Penelitian ini merupakan penelitian kualitatif dengan menggunakan metode fenomenologi pada remaja yang hamil. Hasil penelitian di olah dan dianalisis dengan melewati proses reduksi data dan triangulasi. Hasil penelitian menunjukan bahwa semua informan hamil yang pertama kali, sebagian besar informan sebagai Ibu Rumah Tangga, berpendidikan rendah dan status ekonomi juga rendah. Sebagian besar informan mempunyai pengetahuan yang baik mengenai kehamilan remaja, faktor penyebab dan dampak kehamilan remaja. Diharapkan informan dapat meningkatkan pengetahuannya terkait kehamilan dan persalinan dan melakukan pemeriksaan kehamilan yang adekuat.
\end{abstract}

Kata Kunci : Kehamilan remaja, pengetahuan, pendidikan, pekerjaan, status ekonomi

\begin{abstract}
Adolescence is a transitional period which can cause various health problems namely marriage and early pregnancy, STIs (Sexually Transmitted Infections), ISR (Reproductive Tract Infections), and HIV / AIDS. The incidence of teenage pregnancy throughout the world cannot be estimated with certainty. Around 16 million births occur to mothers aged 15-19 years or 11\% of all births in the world, the majority (95\%) occurring in developing countries. The purpose of this research is to know and explain the factors related to the pregnancy of adolescents in Batam City in 2019. This research is a qualitative study using phenomenology methods in pregnant adolescents. The results of the study were processed and analyzed by going through the process of data reduction and triangulation. The results showed that all informants were pregnant for the first time, most of the informants as housewives, had low education and low economic status. Most of the informants have good knowledge about teen pregnancy, the causes and effects of teenage pregnancy. It is hoped that informants can increase their knowledge related to pregnancy and childbirth and conduct adequate her pregnancy care.
\end{abstract}




\section{Keywords: Teen pregnancy, knowledge, education, employment, economic status}

\section{PENDAHULUAN}

Masa remaja atau masa adolesens adalah suatu fase tumbuh kembang yang dinamis dalam kehidupan seorang individu. Masa remaja berlangsung melalui 3 tahapan yaitu masa remaja awal (10-14 tahun), menengah (15-16 tahun), dan akhir (17-20 tahun) (Ikatan Dokter Anak Indonesia, 2013). Sifat khas remaja mempunyai rasa keingintahuan yang besar, menyukai petualangan dan tantangan serta cenderung berani menanggung risiko atas perbuatannya. Sifat dan prilaku berisiko pada remaja tersebut memerlukan ketersediaan pelayanan kesehatan peduli remaja yang dapat memenuhi kebutuhan kesehatan remaja termasuk pelayanan untuk kesehatan reproduksi (Pusat Data Informasi, 2015).

Kesehatan Reproduksi adalah suatu keadaan sejahtera fisik, mental dan social yang utuh, bukan hanya bebas dari penyakit atau kecacatan dalam segala aspek yang berhubungan dengan system reproduksi, fungsi, dan prosesnya (Rohan, 2017:2). Kesehatan Reproduksi Remaja adalah suatu kondisi sehat yang menyangkut sistem, fungsi dan proses reproduksi yang dimiliki oleh remaja. Pada masa remaja memiliki permasalahan, masalah kesehatan reproduksi remaja yaitu Perkawinan dan kehamilan usia dini, IMS (Infeksi Menular Seksual)), ISR (Infeksi Saluran Reproduksi), HIV/AIDS (human immunodeficiency virus / Acquired Immune Deficiency Syndrome). (Harnani, 2015:9).

Masalah pada remaja diantaranya yang berhubungan dengan kesehatan reproduksi, yaitu remaja dengan kehamilan dibawah usia 20 tahun sebesar 32\%, dengan persalinan dibawah usia 20 tahun sebanyak 14,7\%, Infeksi Saluran Reproduksi sebesar 7\%, Infeksi Menular Seksual (IMS) sebesar 0\%, dan HIV/AIDS sebesar 0\% (Dinas Kesehatan Kota Batam, 2018). Pusat Data Informasi Kementrian Kesehatan Republik Indonesia
(Pusdatin Kemenkes RI), 2013 menunjukkan bahwa angka kejadian kehamilan remaja di Indonesia adalah 1,97\% (Pusdatin Kemenkes RI, 2013).

Data Dinas Kesehatan Kota Batam menunjukkan ada 3 Puskesmas dengan angka kehamilan pada usia remaja ( $<20$ tahun) yang tertinggi di Kota Batam, yaitu di Puskesmas Sambau sebesar 17,46\%, kemudian Puskesmas Lubuk Baja sebesar 17,46\%, dan Puskesmas Bulang sebesar 12,69\%. Dari hasil studi pendahuluan yang dilakukan terhadap puskesmas Sambau, Bulang dan Lubuk Baja, didapatkan Puskesmas sambau sebanyak 2 kasus, dan Puskesmas Bulang sebanyak 6 kasus kejadian Kehamilan Usia Remaja.

Untuk mendapatkan pelayanan kesehatan yang optimal, diwujudkan melalui pemberian pelayanan antenatal sekurangkurangnya empat kali selama masa kehamilan, dengan distribusi waktu minimal satu kali pada trimester pertama (usia kehamilan 0-12 minggu), satu kali pada trimester kedua (usia kehamilan 12-24 minggu), dan dua kali pada trimester ketiga (usia kehamilan 24 minggu sampai persalinan) (Profil Kemenkes Indonesia, 2014) .

Secara kuantitas, jumlah Puskesmas PONED dan RS PONEK meningkat namun belum diiringi dengan peningkatan kualitas pelayanan. Peningkatan kesehatan ibu sebelum hamil terutama pada masa remaja, menjadi faktor penting dalam penurunan AKI dan AKB. Peserta KB cukup banyak merupakan potensi dalam penurunan kematian ibu, namun harus terus digalakkan penggunaan kontrasepsi jangka panjang. Keanekaragaman makanan menjadi potensi untuk peningkatan gizi ibu hamil, namun harus dapat dikembangkan paket pemberian makanan tambahan bagi ibu hamil yang tinggi kalori, protein dan mikronutrien (Kemenkes RI, 2015). Berdasarkan latar belakang diatas, maka peneliti tertarik untuk melakukan penelitian tentang Analisis Faktor 
Kehamilan Pada Usia Remaja di Kota Batam 2019

\section{METODE PENELITIAN}

Metode penelitian ini adalah sebuah penelitian kualitatif yang didasarkan pada fenomena, gejala, fakta, atau informasi sosial. Metode kualitatif yaitu proses berpikir yang dimulai dari data yang dikumpulkan kemudian diambil kesimpulan secara umum. Bertujuan untuk menjawab bagaimana suatu fenomena itu terjaadi, atau mengapa terjadi (Notoatmodjo,2010). Teknik penentuan sampel yang digunakan pada penelitian ini adalah dengan mengguanakan teknik sampel non-probabilitas yang cenderung bersifat kualitatif. Untuk menjawab permasalahan khusus yang sulit diungkapkan dan tidak mudah dianalisis secara statistik, maka teknik sampling non-probabilitas akan lebih tepat dan dapat lebih berguna dalam proses pengumpulan data. Dalam penelitian dengan metode kualitatif, ukuran sampel tidak menjadi permasalahan, namum yang paling penting adalah kelengkapan data.

Cara pengumpulan data dalam penelitian ini adalah dengan observasi partisipan, wawancara mendalam dan terstruktur, dokumentasi dan tinjauan Literatur. Pengumpulan data ini dilakukan antara informan atau responden dengan pewawancara yang ditandai dengan penggalian mendalam tentang segala sesuatu masalah penelitian dengan menggunakan pertanyaan terbuka (Lapau Buhari, 2015).

Cara pengumpulan data pada penelitian ini juga menggunakan teknik Focus Group Discution (FGD). FGD adalah upaya menggali informasi dari beberapa orang sekaligus dalam kelompok. Peneliti memberikan beberapa pertanyaan untuk responden dengan menjawab yang berbedabeda dalam kelompok tersebut (Notoatmodjo, 2010). Teknik analisis data yang digunakan dalam penelitian kualitatif mencakup transkip hasil wawancara, reduksi data, analisis, interpretasi data dan triangulasi. Dari hasil analisis data yang kemudian dapat ditarik kesimpulan

\section{HASIL PENELITIAN}

\section{A. Karakteristik Informan}

\section{Tabel 1. Karakteristik Informan}

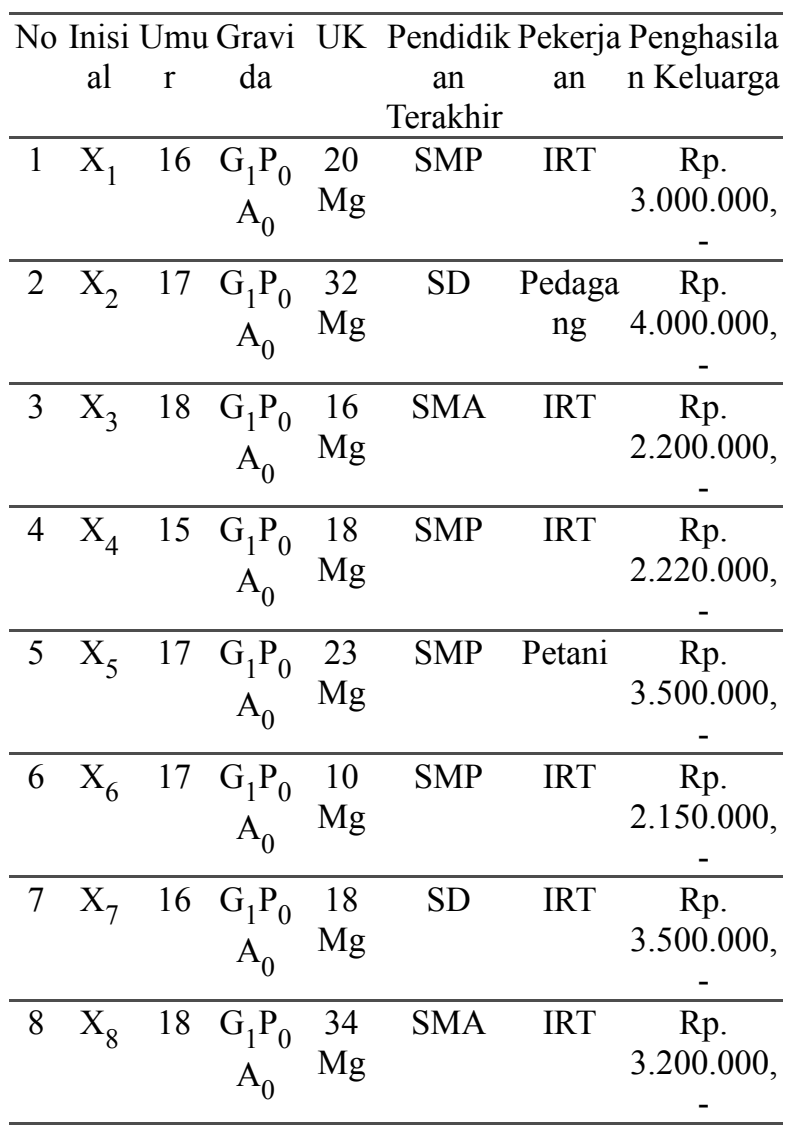

Tabel 1 menunjukkan bahwa dari 8 orang remaja yang hamil yang menjadi informan terdapat $8(100 \%)$ orang termasuk dalam kategori ibu hamil dengan umur resiko tinggi. Data pendidikan terakhir remaja hamil yang menjadi informan terdapat $2(25 \%)$ remaja dengan pendidikan terakhir $\mathrm{SD}, 4$ (50 \%) pendidikan terakhir SMP dan terdapat 2 (25\%) remaja hamil dengan pendidikan terakhir SMA. Data Gravida menunjukkan 8 $(100 \%)$ merupakan kehamilan pertama. Data usia kehamilan menunjukkan 1 (12.5\%) TM I, 5 (62.5\%) TM II dan 2 (25\%) memasuki TM III.

Data pekerjaan remaja hamil yang menjadi informan terdapat $6(75 \%)$ remaja dengan dengan pekerjaan sebagai Ibu Rumah 
Tangga (IRT), 1 (12.5\%) bekerja sebagai pedagang dan $1(12,5 \%)$ bekerja sebagai petani. Data penghasilan keluarga remaja hamil yang menjadi informan terdapat 7 $(87.5 \%)$ dengan penghasilan lebih rendah dari UMK Kota Batam, dan hanya 1 (12.5\%) bekerja dengan penghasilan diatas UMK Kota Batam

\section{B. Hasil Wawancara Mendalam Pada Remaja}

Hasil wawancara sudah melewati tahap reduksi data dengan bahasan : Karakteristik Remaja, Pengetahuan tentang Kehamilan Remaja, faktor penyebab dan dampak kehamilan remaja.

1. Pengetahuan Remaja tentang Kehamilan Remaja

Tabel 2. Pengetahuan Informan tentang Pengertian IMS

\begin{tabular}{|c|c|c|}
\hline No & Inisial & Pernyataan \\
\hline 1 & $\mathrm{X} 1$ & $\begin{array}{l}\text { Kehamilan remaja merupakan } \\
\text { kehamilan pada anak kecil yang tidak } \\
\text { melanjutkan sekolah karena sudah } \\
\text { menikah }\end{array}$ \\
\hline 2 & $\mathrm{X} 2$ & $\begin{array}{l}\text { Kehamilan remaja adalah anak remaja } \\
\text { yang hamil diluar nikah karena } \\
\text { melakukan hubungan badan }\end{array}$ \\
\hline 3 & X3 & $\begin{array}{l}\text { Kehamilan remaja adalah kehamilan } \\
\text { yang terjadi pada anak usia remaja } \\
\text { atau masih kecil }\end{array}$ \\
\hline 4 & $\mathrm{X} 4$ & $\begin{array}{l}\text { Kehamilan remaja adalah anak remaja } \\
\text { yang melakukan hubungan badan dan } \\
\text { hamil jadi harus menikah }\end{array}$ \\
\hline 5 & X5 & $\begin{array}{l}\text { Kehamilan remaja merupakan akibat } \\
\text { dari pergaulan bebas dan ada yang } \\
\text { disuruh orang tua menikah }\end{array}$ \\
\hline 6 & X6 & $\begin{array}{l}\text { Kehamilan remaja adalah kehamilan } \\
\text { yang terjadi pada anak usia remaja }\end{array}$ \\
\hline 7 & X7 & $\begin{array}{l}\text { Kehamilan remaja adalah anak remaja } \\
\text { yang hamil diluar nikah karena } \\
\text { melakukan hubungan badan }\end{array}$ \\
\hline 8 & $\mathrm{X} 8$ & $\begin{array}{l}\text { Kehamilan remaja adalah kehamilan } \\
\text { yang terjadi pada anak usia remaja } \\
\text { atau kurang dari } 20 \text { tahun }\end{array}$ \\
\hline
\end{tabular}

Berdasarkan berbagai pernyataan yang disampaikan oleh informan tentang pengertian Kehamilan Remaja, dapat disimpulkan bahwa hampir semua informan mengetahui tentang kehamilan remaja yang didefinisikan kehamilan yang terjadi pada usia remaja baik itu dikarenakan akibat perilaku seksual baik disengaja (sudah menikah) maupun tidak disengaja (belum menikah).

\section{Faktor Penyebab Kehamilan Remaja}

Tabel 3. Pengetahuan Informan tentang Penyebab Kehamilan Remaja

\begin{tabular}{|c|c|c|}
\hline No & Inisial & Pernyataan \\
\hline 1 & X1 & $\begin{array}{l}\text { Penyebab kehamilan remaja karena } \\
\text { remaja tersebut tidak sekolah jadi } \\
\text { mau ngapain lagi lebih baik menikah }\end{array}$ \\
\hline 2 & $\mathrm{X} 2$ & $\begin{array}{l}\text { Penyebab kehamilan remaja karena } \\
\text { berhubungan badan dengan pacar. } \\
\text { Khawatir jika pacar saya } \\
\text { meninggalkan saya jadi harus segera } \\
\text { menikah }\end{array}$ \\
\hline 3 & $\mathrm{X} 3$ & $\begin{array}{l}\text { Penyebab kehamilan remaja } \\
\text { dikarenakan pergaulan bebas, faktor } \\
\text { ekonomi dan sudah dibilang tua oleh } \\
\text { keluarga sehingga harus segera } \\
\text { menikah }\end{array}$ \\
\hline 4 & $\mathrm{X} 4$ & $\begin{array}{l}\text { Penyebab kehamilan remaja karena } \\
\text { tidak sekolah dan teman-teman sudah } \\
\text { menikah semua }\end{array}$ \\
\hline 5 & X5 & $\begin{array}{l}\text { Penyebab kehamilan remaja } \\
\text { dikarenakan pergaulan bebas, mabuk- } \\
\text { mabukan }\end{array}$ \\
\hline 6 & X6 & $\begin{array}{l}\text { Penyebab kehamilan remaja karena } \\
\text { kemauan orang tua dan saya memang } \\
\text { mau menikah muda }\end{array}$ \\
\hline 7 & X7 & $\begin{array}{l}\text { Penyebab kehamilan remaja karena } \\
\text { tidak mau menyusahkan orang tua } \\
\text { dan saya tidak melanjutkan sekolah }\end{array}$ \\
\hline 8 & X8 & $\begin{array}{l}\text { Penyebab kehamilan remaja } \\
\text { dikarenakan pacaran yang berlebihan } \\
\text { dan tidak mau lagi bergantung dengan } \\
\text { orang tua }\end{array}$ \\
\hline
\end{tabular}

Berdasarkan berbagai pernyataan yang disampaikan oleh informan tentang pengertian faktor penyebab Kehamilan Remaja, dapat disimpulkan bahwa hampir 
semua informan mengetahui tentang penyebab kehamilan remaja yaitu pergaulan bebas, faktor ekonomi, peran orang tua dan tidak melanjutkan pendidikan

\section{Dampak Kehamilan Remaja}

\section{Tabel 4. Pengetahuan Informan tentang Dampak Kehamilan Remaja}

\begin{tabular}{|c|c|c|}
\hline No & Inisial & Pernyataan \\
\hline 1 & $\mathrm{X} 1$ & $\begin{array}{l}\text { Dampak nya tidak ada menurut saya } \\
\text { tapi awal hamil itu saya merasakan } \\
\text { sangat tidak nyaman karena gak bisa } \\
\text { makan dan sering muntah sehingga } \\
\text { saya lemas sekali }\end{array}$ \\
\hline 2 & $\mathrm{X} 2$ & $\begin{array}{l}\text { Dampak kehamilan remaja yaitu } \\
\text { berbahaya karena masih kecil dan } \\
\text { belum bisa mengurus anak }\end{array}$ \\
\hline 3 & X3 & $\begin{array}{l}\text { Dampak kehamilan remaja mungkin } \\
\text { bisa terjadi keguguran karena masih } \\
\text { kecil itu belum boleh hamil }\end{array}$ \\
\hline 4 & $\mathrm{X} 4$ & $\begin{array}{l}\text { Dampak kehamilan remaja adalah } \\
\text { bisa membuat remaja tersebut stress } \\
\text { seperti yang saya rasakan diawal } \\
\text { kehamilan karena saya belum siap } \\
\text { dan saya sering sakit }\end{array}$ \\
\hline 5 & $\mathrm{X} 5$ & $\begin{array}{l}\text { Dampak kehamilan remaja bagi saya } \\
\text { adalah saya sering cemas dan merasa } \\
\text { belum siap menjadi seorang ibu. } \\
\text { Terkadang saya berfikir saya mau } \\
\text { sekolah lagi }\end{array}$ \\
\hline 6 & X6 & $\begin{array}{l}\text { Dampak kehamilan remaja, saya } \\
\text { merasakan sangat berat hamil ini. } \\
\text { Sekarang berat badan saya turun } \\
\text { karena saya tidak nafsu makan dan } \\
\text { sering muntah, badan saya sakit-sakit } \\
\text { dan saya khawatir dengan bayi } \\
\text { didalam perut ini }\end{array}$ \\
\hline 7 & X7 & $\begin{array}{l}\text { Dampak kehamilan remaja adalah } \\
\text { saya sering berfikir apakah bisa } \\
\text { menjadi seorang ibu dan sering } \\
\text { memikirkan biaya yang harus } \\
\text { dikeluarkan nantinya }\end{array}$ \\
\hline 8 & X8 & $\begin{array}{l}\text { Dampak kehamilan remaja bagi saya, } \\
\text { saya tidak bisa kuliah dulu padahal } \\
\text { saya mau kuliah seperti teman-teman } \\
\text { saya yang lain }\end{array}$ \\
\hline
\end{tabular}

Berdasarkan berbagai pernyataan yang disampaikan oleh informan tentang dampak Kehamilan Remaja, dapat disimpulkan bahwa hampir semua informan mengetahui tentang dampak kehamilan remaja baik itu dampak fisik maupun dampak psikis yang akan mempengaruhi kesehatan ibu dan janinnya.

\section{PEMBAHASAN}

\section{A. Karakteristik}

\section{Paritas}

Subjek penelitian ini terdiri dari ibu hamil usia remaja di Kota Batam. Semua $(100 \%)$ ibu hamil dalam penelitian ini merupakan kehamilan pertama dan belum pernah melahirkan. Paritas adalah banyaknya kelahiran hidup yang dimiliki oleh seorang wanita (BKKBN, 2010). Menurut Manuaba (2012) paritas merupakan peristiwa dimana seorang wanita pernah melahirkan bayi dengan lama masa kehamilan antara 38 hingga 42 minggu.

Depkes RI (2010) yang menyatakan Ibu yang belum pernah hamil dan bersalin memiliki kecenderungan merasa takut dan cemas menjelang persalinan, hal ini dikarenakan mereka belum pernah memiliki pengalaman sebelumnya, berbeda dengan ibu yang telah pengalaman sebelumnya, mereka akan memiliki kesiapan yang lebih karena belajar dari pengalamannya terdahulu.

Berdasarkan penelitian yang dilakukan oleh Horhoruw (2016) menunjukkan hasil analisis dengan uji chi square diperoleh nilai signifikan 0,009, yang menunjukan bahwa ada hubungan antara paritas dengan tingkat kecemasan ibu dalam menghadapi persalinan pada ibu hamil trimester III di Puskesmas Jetis Kota Yogyakarta. Sejalan juga dengan penelitian yang dilakukan oleh Zulina (2014) yang menunjukkan bahwa 19 responden hampir setengahnya $(41,7 \%)$ adalah nullipara dan sebagian besar responden $(57,10 \%)$ mengalami kecemasan ringan. Hasil uji statistik didapatkan $(0,04)<(0,05), \mathrm{H} 0$ ditolak artinya ada hubungan antara paritas dengan tingkat kecemasan dalam menghadapi persalinan pada ibu hamil trimester III di BPS Zul Choiliyah Surabaya. 
Dari hasil penelitian dapat disimpulkan bahwa paritas empengaruhi tingkat kecemasan ibu hamil dalam menghadapi persalinan. Persalinan merupakan hal yang fisiologis, oleh karena itu dukungan keluarga sangat membantu dalam mengurangi kecemasan menghadapi persalinan.

\section{Pendidikan Terakhir}

Hasil penelitian ini menunjukkan pendidikan terakhir remaja hamil yang menjadi informan terdapat $2(25 \%)$ remaja dengan pendidikan terakhir SD, 4 (50 \%) pendidikan terakhir SMP dan terdapat 2 (25 \%) remaja hamil dengan pendidikan terakhir SMA.

Menurut Hutagalung (2012) bahwa pendidikan sangat erat kaitanya dengan informasi tentang kesehatan reproduksi yang diterima seseorang sehingga dapat membedakan perilaku kesehatan yang benar dan perilaku kesehatan yeng salah. Tingkat pendidikan yang lebih tinggi akan memudahkan seseorang atau masyarakat untuk menyerap informasi dan mengimplementasikannya dalam perilaku dan gaya hidup sehari-hari khususnya dalam hal kesehatan, sehingga tingkat pendidikan formal dapat membentuk nilai bagi seseorang terutama dalam menerima hal baru (Muzaham, 2013).

Penelitian yang dilakukan oleh Realita (2017) tentang hubungan tingkat pendidikan terhadap kejadian kehamilan usia remaja di Rumah Sakit islam Agung Semarang menunjukkan hasil bahwa pendidikan memiliki pengaruh terhadap kehamilan remaja dengan nilai OR 0,057 . Sejalan juga dengan penelitian Rahayu (2017) tentang faktor determinan dan resiko kehamilan remaja di Kecamatan Magelang Selatan yang menunjukkan hasil terdapat hubungan antara pendidikan dengan kehamilan remaja ( $\mathrm{p}=$ 0.048).

Dari penelitian ini dapat disimpulkan bahwa tingkat pendidikan berhubungan dengan kehamilan remaja. Semakin baik tingkat pendidikan seseorang maka akan semakin baik pola fikir yang terbentuk, sehingga pola pikir yang baik tersebut akan membuat seseorang semakin terbuka terhadap hal-hal baru dan mampu menerima informasi dengan baik sehingga memiliki kemampuan berfikir dalam berperilaku (Purwanto, 2011).

\section{Pekerjaan}

Hasil penelitian ini menunjukkan bahwa pekerjaan remaja hamil yang menjadi informan terdapat $6(75 \%)$ remaja dengan dengan pekerjaan sebagai Ibu Rumah Tangga (IRT), $1(12.5 \%)$ bekerja sebagai pedagang dan $1(12,5 \%)$ bekerja sebagai petani. Pekerjaan adalah aktivitas atau kegiatan yang dikerjakan seseorang untuk mendapatkan nafkah, hasil atau pencaharian. Orang yang sibuk dengan kegiatan atau pekerjaan seharihari akan memiliki waktu yang lebih untuk memperoleh informasi karna orang yang bekerja akan lebih banyak berinteraksi dengan orang lain dari pada orang yang tidak bekerja dan beraktivitas.

Berdasarkan penelitian yang ilakukan oleh Kurniawati (2016) tentang hubungan tingkat pendidikan, status pekerjaan dengan kejadian kehamilan remaja menunjukkan hasil tidak ada hubungan pekerjaan dengan kejadian kehamilan remaja dengan nilai chi square status pekerjaan $2,16<$ nilai $\mathrm{x}^{2}$ tabel 5,991 .

Kesimpulan yang bisa ditarik dari penelitian ini bahwa kehamilan remaja bukan karena faktor pekerjaan. Teori Notoatmodjo (2012) yang menyatakan bahwa pekerjaan merupakan salah satu bagian dari faktor sosial yang bersifat dinamis. Suatu lingkungan sosial tertentu tidak begitu saja memberi pengaruh yang sama kepada setiap orang, akan tetapi kebiasaan sosial akan memberi pengaruh terhadap kesehatan. Dengan teori tersebut, maka memberikan makna bahwa pengaruhnya tidak langsung diterima oleh seseorang. Sehingga antara seseorang yang bekerja dan tidak bekerja tidak ada bedanya dalam mendapatkan pengaruh untuk menjalani pernikahan dan kehamilan. 


\section{Penghasilan Keluarga}

Hasil penelitian ini menunjukkan data penghasilan keluarga remaja hamil yang menjadi informan terdapat $7(87.5 \%)$ dengan penghasilan lebih rendah dari UMK Kota Batam, dan hanya 1 (12.5\%) bekerja dengan penghasilan diatas UMK Kota Batam. Penghasilan keluarga merupakan suatu hasil yang diterima oleh seseorang atau rumah tangga dari berusaha atau bekerja (Nazir, 2010). Pendapatan adalah keseluruhan penghasilan yang diterima baik dari sektor formal maupun nonformal yang dihitung dalam jangka waktu tertentu.

Penelitian yang dilakukan Rahayu (2017) tentang faktor determinan dan resiko kehamilan remaja di Kecamatan Magelang Selatan yang menunjukkan hasil terdapat hubungan antara penghasilan dengan kehamilan remaja $(p=0.027)$. Sejalan dengan penelitian Suprianti (2017) tentang hubungan status ekonomi dan pengetahuan terhadap kehamilan remaja di Kecamatan Selo Boyolali menunjukkan ada hubungan antara status ekonomi dengan kehamilan remaja.

Menurut Cahyani (2015) kondisi ekonomi keluarga yang rendah diikuti dengan usia kawin pertama yang rendah pula, dan sebaliknya semakin tinggi kondisi ekonomi keluarga maka semakin tinggi usia kawin pertamanya. Hal ini menunjukkan bahwa pendapatan keluarga berkaitan dengan usia nikah pertama dan kehamilannya, semakin rendah pendapatan keluarga semakin dini kepala keluarga menikahkan anak wanitanya. Tingkat pendapatan keluarga akan mempengaruhi usia nikah muda, hal tersebut di karenakan pada keluarga yang berpendapatan rendah maka pernikahan anaknya berarti lepasnya beban dan tanggung jawab untuk membiayai anaknya.

\section{B. Pengetahuan Informan tentang kehamilan Remaja}

\section{Pengetahuan tentang kehamilan remaja}

Kehamilan remaja adalah kehamilan yang terjadi pada remaja yang merupakan akibat perilaku seksual baik disengaja (sudah menikah) maupun tidak disengaja (belum menikah) faktor-faktor penyebab kehamilan remaja adalah kurangnya peran orang tua dalam keluarga, kurangnya pendidikan seks dari orang tua, dan keluarga terhadap remaja, dan perkembangan iptek yang tidak didasari dengan perkembangan mental yang kuat. Terdapat resiko pada kehamilan remaja jika kehamilan itu dipertahankan atau diakhiri (aborsi). Maka terdapat resiko fisik psikis atau psikologi dan sosial (Dainty, 2017). Dari hasil penelitian dapat disimpulkan bahwa seluruh informan sudah mendapatkan informasi tentang kehamilan remaja

\section{Pengetahuan tentang faktor penyebab kehamilan remaja}

Berdasarkan berbagai pernyataan yang disampaikan oleh informan tentang faktor penyebab kehamilan remaja, dapat disimpulkan bahwa sebagian besar informan mengetahui tentang faktor penyebab kehamilan remaja diantaranya pergaulan bebas, faktor ekonomi, faktor budaya dan keluarga serta rendahnya pendidikan.

Menurut Soetjiningsih (2010), faktorfaktor yang mempengaruhi hubungan seksual yang pertama dialami oleh remaja, yaitu pengaruh pubertas, frekuensi pertemuan dengan pacar, kontrol sosial yang kurang tepat, pola asuh Orang tua, status sosial ekonomi rendah, pengaruh teman sebaya, penggunaan obat-obatan terlarang dan alkohol, penyebaran informasi melalui media massa.

Dari hasil penelitian dapat disimpulkan bahwa seluruh remaja yang menjadi informan sudah mengetahui tentang faktor penyebab kehamilan remaja, meskipun ada sebagian kecil yang menjawab kurang tepat.

\section{Pengetahuan tentang dampak kehamilan remaja}

Berdasarkan berbagai pernyataan yang disampaikan oleh informan tentang dampak 
kehamilan remaja, dapat disimpulkan bahwa sebagian besar informan mengetahui tentang dampak kehamilan remaja diantaranya masalah-masalah pada kehamilan, keguguran, stress dan depresi, masalah ekonomi, berhenti sekolah dan masalah pada janin.

Menurut Soetjiningsih, 2010 Terdapat beberapa resiko untuk kehamilan remaja seperti resiko fisik, resiko psikis atau psikologis, risiko sosial, resiko ekonomi dan berbagai komplikasi kehamilan usia remaja diantaranya yaitu : Keguguran, persalinan prematur, berat badan lahir rendah (BBLR) dan kelainan bawaan, mudah terjadi infeksi, anemia kehamilan, keracunan Kehamilan (Gestosis) bahkan kematian ibu.

Dari hasil penelitian dapat disimpulkan bahwa seluruh remaja yang menjadi informan sudah mengetahui tentang dampak kehamilan remaja, meskipun ada sebagian kecil yang menjawab kurang tepat.

\section{KESIMPULAN}

Berdasarkan kegiatan-kegiatan yang telah dilaksanakan, kesimpulan sementara yang diperoleh adalah :

1. Informan 8 orang remaja yang hamil menunjukkan data pendidikan terakhir remaja hamil yang menjadi informan terdapat $2(25 \%)$ remaja dengan pendidikan terakhir SD, $4 \quad(50 \%)$ pendidikan terakhir SMP dan terdapat 2 (25\%) remaja hamil dengan pendidikan terakhir SMA. Data Gravida menunjukkan $8(100 \%)$ merupakan kehamilan pertama. Data usia kehamilan menunjukkan 1 (12.5\%) TM I, 5 (62.5\%) TM II dan 2 (25\%) memasuki TM III. Data pekerjaan remaja hamil yang menjadi informan terdapat $6(75 \%)$ remaja dengan dengan pekerjaan sebagai Ibu Rumah Tangga (IRT), $1(12.5 \%)$ bekerja sebagai pedagang dan $1(12,5 \%)$ bekerja sebagai petani. Data penghasilan keluarga remaja hamil yang menjadi informan terdapat $7 \quad(87.5 \%)$ dengan penghasilan lebih rendah dari UMK Kota Batam, dan hanya 1 (12.5\%) bekerja dengan penghasilan diatas UMK
Kota Batam

2. Sebagian besar remaja mempunyai pengetahuan yang baik tentang kehamilan remaja, faktor penyebab dan dampak kehamilan remaja.

\section{SARAN}

Hasil penelitian ini diharapkan dapat membantu petugas kesehatan dalam memberikan pendidikan kesehatan dan penyuluhan kepada remaja agar bisa mempersiapkan kehamilan pada usia yang tidak beresiko.

\section{DAFTAR PUSTAKA}

Ayalew M, Mengistie B, Semahegn A. 2014. Adolescent parent communication on sexual and reproductive health issues among high school students in Dridawa, Eastern Ethiopia: Reproductive Health

Data PKPR Puskesmas Bulang Kota Batam (2018). Data Laporan PKPR tahun 2017.

Dewi, 2012. Kesehatan Reproduksi Remaja dan Wanita, Jakarta : Salemba Medika.

Dinas Kesehatan Kota Batam, 2016. Data Masalah Remaja di Kota Batam Tahun 2017.

Isa I, Gani O. 2012. Socio-demographic determinants of teenage pregnancy in the Niger Delta of Nigeria. Open Journal of Obstetrics and Gynecology

Jones N, Tefera B, Stephenson J, Gupta T, Pereznieto P, Emire G, et al. 2014. Early marriage and education the complex role of social norms in shaping Ethiopian adolescent girls' lives: Overseas Development Institute

Kumalasari, 2012. Kesehatan Reproduksi. Jakarta : Salemba Medika.

Kusmiran, E. 2011. Kesehatan Reproduksi Remaja dan Wanita. Jakarta : Salemba Medika.

Marmi, $2013 \quad$.KesehatanReproduksi. Yogyakarta: Pustaka Pelajar.

Maternity, dkk. 2017. Asuhan Kebidanan Komunitas. Yogyakarta : CV. Andi 
Offset.

Mekonnen WA. 2013. Differentials of early teenage pregnancy in Ethiopia, 2000, and 2005: ICF International Calverton, Maryland, USA

Mchunu G, Peltzer K, Tutshana B, Seutlwadi L.2012. Adolescent pregnancy and associated factors in South African youth: African Health Sciences

Notoadmodjo, S. 2010. Metode Penelitian Kesehatan. Jakarta : Rineka Cipta.

Nugroho. 2011. Buku Ajar Obstetri untuk Mahasiswa Kebidanan. Yogyakarta : Nuha Medika.

Nursalam. 2013. Metodologi Penelitian Ilmu Keperawatan. Jakarta : Salemba Medika.

Prawirohardjo. 2014. Ilmu Kebidanan. Jakarta : PT Bina Pustaka.

Profil Dinas Kesehatan Kota Batam. 2017.Riskesdas, 2013. Kementrian Kesehatan Tentang Proporsi Kehamilan Remaja. Oleh Pusdatin 2015.

Pudiastuti, 2011. Buku Ajar Kebidanan Komunitas. Yogyakarta : Nuha Medika.

Ramlah, (2017). Asuhan Kebidanan Kesehatan Reproduksi Pada Remaja dengan Kehamilan Usia Remaja di Wilayah Kerja Puskesmas Sambau Kota Batam, Karya Tulis Ilmiah Studi Kasus, Batam. Program Studi D-III Kebidanan Stikes Mitra Bunda Persada Batam Tahun 2017.

Rutgers and the Government of Ethiopia. Fact sheet developed for the High-Level Political Forum Roundtable Discussion on Preventing Teenage Pregnancies. 2017.

SofõÂa L, Latorre C, Tovar JR. 2014. Risk factors for adolescent pregnancy in BogotaÂ , Colombia, 2010: a casecontrol study: Pan American Journal of Public Health

Sulistyawati, 2013. AsuhanKebidananPada Masa Kehamilan. Jakarta :Salemba Medika.

Walyani, 2014. Materi Ajar Lengkap Kebidanan Komunitas. Yogyakarta : Pustaka Baru.
Widyastuti dkk, 2010. Kesehatan Reproduksi. Yogyakarta: Fitra Maya.

Yakubu I, Salisu WJ. 2018. Determinants of adolescent pregnancy in sub-Saharan Africa: a systematic review. Reproductive Health

Yuni Dwi Lestari, 2016. Asuhan Kebidanan Pada Ibu Hamil Usia Remaja di Puskesmas Panjatan It Kulon Progo, Karya Tulis Ilmiah Studi Kasus. Yogyakarta. Program Studi Kebidanan Jenjang Diploma III Sekolah Tinggi Ilmu Kesehatan 'Aisyiyah Yogyakarta Tahun 2016.

Wall-Wieler E, Roos LL, Nickel NC. 2016. Teenage pregnancy: the impact of maternal adolescent childbearing and older sister's teenage pregnancy on a younger sister. BMC Pregnancy and Childbirth

World Health Organization (WHO).Departement of Reproductive Health and Research : Geneva

World Health Organization (WHO).2012. Early marriages, adolescent and young pregnancies 